\title{
THE IMPACT OF TEACHERS NON-VERBAL QUESTIONING BEHAVIOR ON STUDENT PARTICIPATION IN THE CLASSROOM
}

\author{
Asrori \\ The State University of Surabaya, English Department, \\ Surabaya, East Java, Indonesia \\ e-mail:asrori@unesa.ac.id
}

\begin{abstract}
Questioning has been becoming the subject of the study since it is regarded as one of the most important ways to maintain the classroom interaction. Several studies have been carried out on the use of questions but most of them are focused on the type of questions used by the teacher. Moreover, the teacher often neglects their non-verbal behavior when they deliver questions to the students. Hence, this study investigates the impact of teachers nonverbal questioning behavior on the students' participation. The study was conducted with teacher and students of State University of Surabaya (UNESA). The data were the conversations between teacher and students in the Reading classroom taken through video recording and observation. The result of the study shows that teacher's nonverbal questioning behavior affects much on the students' participation in the classroom. Maintaining eye contact to the students while asking questions gives a good effect on keeping the students participation. Moreover, the appropriate use of other nonverbal questioning behaviors such as calling the students while asking, giving a right wait time, handling the students' answer positively, also give positive effect on the students participation.
\end{abstract}

Keywords: non-verbal questioning behavior, students' participation 


\section{INTRODUCTION}

Classroom discourse has become the subject where some teachers/researchers pay attention much. Classroom discourse is one of the discourses that happens part in the classroom. Richards, et.al (1992:52) define classroom discourse as one of the types of discourse happens in the classroom. It focuses on the language used by the teacher and students in the process of teaching learning. It is also called as pedagogic discourse and different in its form and function from language used in different situation because of the distinct social roles of students, lecturers, and activities they are engaged in.

Nunan (1993) says that classroom discourse is a type of discourse that happens in the classroom. It is the use of spoken language by teachers and students in the classroom. Richards, et.al (1992:52) define classroom discourse as the type of discourse or the use of language in the classroom. This lecturer-student discourse is also referred to as pedagogic discourse, and of course the languages found in the classroom used by teachers and students has different form and function from the languages used outside the classroom because the distinct social roles of students, teachers, and activities they are engaged in.

The use of questions takes a big part in the classroom. Most of time in the classroom used by the teacher and students to deliver and answer the questions. As what is suggested by . Chaudron (1988) that questions take 20-40 percent of classroom talk, while Tsui (1995) identified where almost 70 percent of classroom interaction consists of the questions delivered by the teacher, responses of the students on the questions, and feedback given by the teacher on the students' response. Questions themselves, take some important roles in the. Hall (2011) says that questions help lecturers elicit information, check learners' understanding and keep learners' attention. They also provide learners with a language practice opportunity when they answer. Lecturer questions, therefore, fulfill a clear pedagogic purpose and also enable lecturers to exert control over learners.

Several studies have been done by the researchers on the questions especially about their effects on the students' participation. The focus of the researches were mostly on the use of the type of the questions (verbal) while non-verbal questioning behavior is neglected though it also takes some effects on the students' participation. Thus this study focused on the effect of non-verbal questioning behavior on students' participation in the classroom.

\section{RESEARCH METHOD}

The focus of this study was the interaction between the teacher and students of The State University of Surabaya especially the use of non-verbal questioning behavior by the teacher while conducting teaching. The study investigated how nonverbal questioning behavior carried out by the teacher affected the students participation in the classroom.

This study used descriptive qualitative design since the data was in the form of words. The data were taken from the conversation and teacher and students' behavior in the classroom. Descriptive qualitative research described the phenomenon happened in the Reading classes of the English Department of State University of Surabaya in the form of words instead of numbers. The phenomena dealt with the use of non-verbal questioning behavior by the teacher and its effect to the students' participation.

The subjects of this study were a lecturer and 6 semester students of English Department of State University of Surabaya (UNESA). A Scientific Reading class was 
chosen class was chosen by consideration that this class requires much interaction between lecturer and students. Scientific Reading is an advance Reading where students are required to be able to explain the content of the text, to paraphrase, and make a summary of the text. Other than that, students are also required to explain and criticize academic articles, research articles, and books. Moreover, the students are required to answer the questions provided by the lecturer and also the reading books used by the lecturer.

The result of the observation and transcribed data obtained from the three meetings of Scientific Reading class were then analyzed. First, the researcher identified the lecturer questions and also students' response toward the lecturer questioning behavior. Second, from the result of the teacher questioning behavior, then the researcher analyzed the effect toward students' response.

\section{QUESTIONING BEHAVIOR}

In some cases, teachers are not really aware with their questioning behavior. They just conduct the class and deliver the questions as their ways. Unfortunately, the use of inappropriate behavior of asking questions will give an impact toward students' response. Teachers should learn some strategies and behavior before questions in their classrooms. Orlich et al. (2004:244) remind us to avoid using questioning for "punitive purposes" because it can make the learning process. Another questioning strategy when asking that the teacher should pay attention is pausing. For Orlich et al. (2004) and many other psychologists, questioning is a process of "asking the question, pausing, and then calling on a student". Nonverbal questioning such as pointing or nodding to students to answer is another important behavior in asking questions. All these nonverbal behaviors, and others, help the teacher to make correct and meaningful questions because they activate the learners' participation, understanding, and communication. Here are some questioning behavior that should be used by teacher when they are in teaching and learning process.

\section{A. Using Gestures}

Nonverbal behavior of delivering questions is as important as the verbal behavior to maintain the communication between teacher and students in the classroom. tHe teacher should try to make a balance when she/he is asking the questions and handling students' response. The teacher's nonverbal questioning behavior, such as eye contact, nodding, facial expressions, and hand gestures, can help him delivering good and effective questions and get good responses. When the teacher uses using nonverbal questioning behavior, he/she should see it as "seeking knowledge" rather than "interrogating the troops" (Davis, 1993, p. 83). Paying attention on the eye contact to the students when he/she is delivering questions will give a good impact on them that they will feel that the teacher pay attention on them and are interested to their. This act then makes the students feel confident and have high motivation to participate in the classroom.

\section{B. Wait Time}

Wait time is the time given between asking questions and pointing/calling students and the time give to the pointed students or others to think of their responses/answers Orlich, et al.,(2004). It is one of the important elements in teaching and learning process because it gives the students time to think of the response/answer 
of the questions given by the teacher. Not only for students, wait time also gives the teacher to students' nonverbal signals that indicate excitement, fright, shame, interest, apprehension, etc. Orlich, et al. believe that if the teachers become more sensitive to "humanitarian consideration", the dimension of teaching becomes very important.

\section{Handling Students' Responses}

In teaching and learning process, there should be communication happens between students and teacher. One of them in questioning and answering session. In many occasions, most teachers don't pay attention on the behavior on how he or she handles the students' questions. On the other hand, handling the students.response becomes a very important behavior that the teacher should pay attention on. The correct response to the students' answer given by the teacher to the questions will give good effects on the students and vise versa. Orlich, et al. (2004:248) says that negative words given to the students' response like "Very bad answer", / "You are wrong" will discourage students and will give bad impacts to them. Moreover, that will reduce students' participation and motivation. Questions shouldn't be used for punishing students because this can make the students to keep silent in the learning process and "turns of" the learner instead of being active in the classroom.

\section{RESULTS AND DISCUSSION}

\section{A. The Use of Gestures}

One of the focuses of the researchers is on the use of gestures by the lecturer when she was teaching the students. The gestures mostly used by the lecturer were maintaining eye contacts, nodding the head, hand gesturing, and facial expression. From its quantity, the use of gestures like maintaining eye contacts, nodding the head, hand gesturing and facial expression were used dirreferently by the lecturer. She used eye contact much more than other behaviors. Maintaining eye contact when asking questions gave a good effect to the students. From the observation, it was seen that the use of eye contact gave good effects on the students. Students tended to pay attention more to the lecturer when she maintained eye contact on them. The students seen it as a signal of interest, boredom, empathy, hostility, attraction, understanding, misunderstanding, and other messages. Moreover the various non-verbal behaviors employed by the lecturer both when she was delivering the questions and giving response to the students answer encourage the students to get involved more in the classroom.

\section{B. The Use of Wait Time}

The above explanation about wait time says that wait time is divided into two: (1) wait time 1 that is the time between delivering questions and calling on the students and (2) wait time 2 that is the time given to the students called to answer the questions or other students to think their response.. Graph 1 shows the percentages of wait time 1 used by the lecturer. 


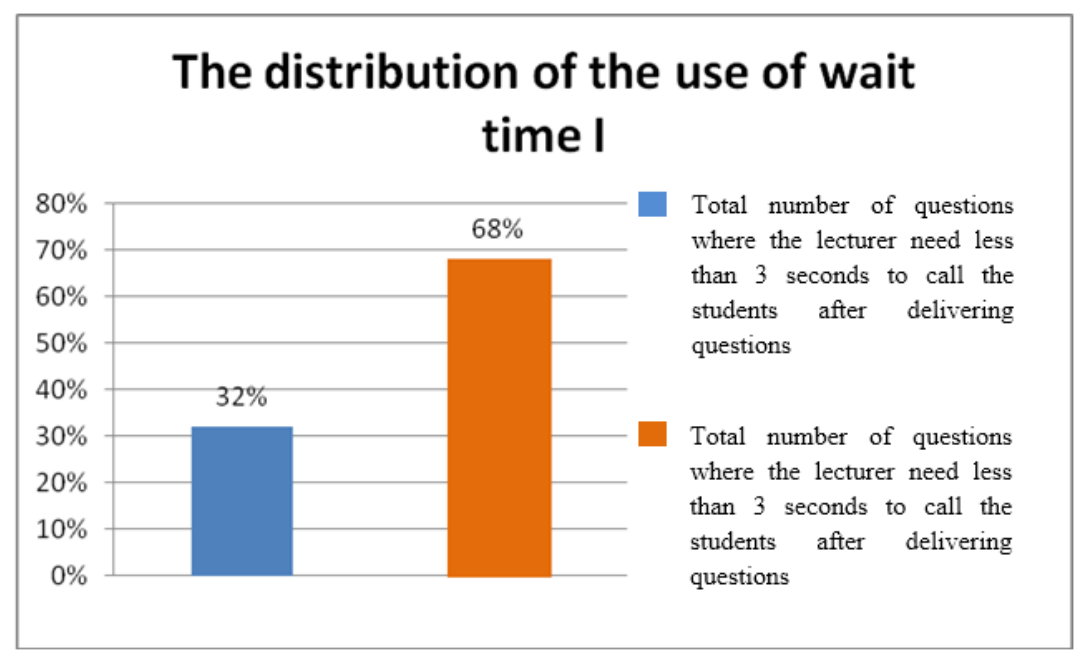

Figure 1: The use of wait time 1 by the lecturer

Figure 1 showed about the wait time 1 used by the lecturer whe she was teaching. It was divided into two based on the seconds needed. They were more than 3 seconds and less than 3 seconds. From the figure it could be seen that the lecturer mostly gave the students less than 3 seconds to answer the questions. It took $68 \%$ of the questions asked. The rest of the $32 \%$, the lecturer gave more than 3 seconds for the students to answer. The two different times were used in delivering different questions. From the observation, it was shown that the lecturer gave students not more than 3 seconds when she asked lower-level questions. The excerpt below were some examples of the case where the students were given less than 3 seconds to answer the questions

[10] L : I had no vacation plans because I was down to my last dime. What is it?

Ss : don't have money.

L : didn't have much money, he was broke, bokek.

My check from home had not arrived on schedule-probably because of the crush of the holiday season-leaving me stranded. What is stranded?

Ss : terdampar.

L : I discovered that my friends had thoughtfully left behind enough food for a poor-man's feast: cans of tuna, boxes of Rice-a-Roni, cartons of eggs, loaves of bread and many bags of tea. So I ate omelets for brunch and improvised dinner casseroles. Often I left the oven door open after heating up a casserole to let a bit of heat circulate in the cold apartment. Why did he do so? What is his reason?

$\mathrm{S}$ : because he celebrates his Christmas alone in the house

$\mathrm{L}$ : and then what happened?

$\mathrm{S}$ : because he has no money

L : he had no money to.

$\mathrm{S}$ : he had no money to ask the gas company to turn on the heat in our quarters.. 
[11] L : ok one by one. he was good with his hand. what does it mean? yang lain diam.

$\mathrm{S}$ : in doing the experiment.

$\mathrm{L}$ : in doing experiment. can we say that he was skillful?

$S$ : yes

$\mathrm{L}$ : ya . in doing things. ok he liked using his head?

$\mathrm{S}:$ hmmm while he good in skills in experiments he also has brain eee

$\mathrm{L}$ : he has brain? everybody has brain. apa?

$\mathrm{S}$ : smart.

L : using his head!

$\mathrm{S}$ : hard thinker

$\mathrm{S}$ : Use his logic

$\mathrm{L}$ : good use his logic. he is logical. he use his logic to do something misalnya. he is smart., he is intelligent. jadi tidak asal-asalan bekerja itu. haaa. and a little daring

S : brave and willing to decrease

$\mathrm{L}$ : yaaa he is willing to decrease whenever he does something. in short he was like any other man anywhere who is happy on his work. so he is a hard worker he is happy. he enjoyed his work. ok slotin. continue please.

$\mathrm{S}$ : (continue reading)

L : what does it mean? each of which alone is too small to be dangerous and which will only sustain a chain reaction when the are put together

$\mathrm{S}$ : the pieces of plutonium.

$\mathrm{L}$ : ya so what does it mean. is plutonium dangerous?

$\mathrm{S}$ : no if its separated.

$\mathrm{L}$ : if it stands by itself it is not dangerous.

$\mathrm{S}$ : when the are put together can be very dangerous

Excerpt [10] \& [11] are examples where the lecturer asked some questions to the students related to the topic that was Room for one more \& Moral for Any Age. She just gave time not more than 3 seconds for the students to answer the questions because the questions were all low level questions and the students didn't need much time to think about the answer because it had been stated in the text. That's why then, the students didn't find any difficulties to answer the questions.

The lecturer, on the other hand, also gave time to the students more than 3 seconds to answer the questions. She did it to the high-level questions when the students needed to think more abut their answer and comprehend the reading before answering. This way succeeded to make the students gave the right response/answer to the questions given. Moreover, it also

[12] L : so what is then the relationship?

$\mathrm{S} \quad$ : the title and the story?

$\mathrm{L}$ : yes.

S (1) : the relationship between the title and the story is when he spent his holiday, his friend, Maria, not his friend actually, the secretary manned of the office, invited him to spend the holiday, spend the Christmas eve with her family.

L : so? Room for One More.. 
S (2) : I think the room itself here is a kind of a place means that Maria invited him means that Maria gave him a place for the writer to enjoy to celebrate the Christmas eve with her family. I think the room itself .......

In the question above, the lecturer gave more than 3 seconds for the students to answer the questions. Though the question was a display question where the lecturer knew the answer, the students needed time to comprehend the text before answering the question. It also opened different answers based on the students' comprehension on the text. in Some cases, the lecturer needed to paraphrase the questions and gave longer time for the students to answer the questions as what can be seen in the excerpts below.

[13] $\mathrm{T}$ : Ya.. the assistant or the workers who help the expert. Slaugted...... what is the purpose of slaugting in doing this...sssst...virlia. yang lain kalo bisa keeping by yourselves nanti I will ask you. what is the purpose? slaughting to do it. is there any special purpose for him to do it?

$\mathrm{V}$ : silent

$\mathrm{T}$ : so what about the others. raise your hand. who can help virlia.

$S$ : to stop the chain reaction.

$\mathrm{T}$ : ya. so there is certain purpose. so why did he do that is to stop the chain reaction. why did he do that?

$\mathrm{S}$ : in order the radioactivity will stop. will disappear. so the plutonium will not explode.

$\mathrm{T}$ : iyaaaa in order that the plutonium wont explode. try to make it spread it." this was... virtually.... what does it mean?

$\mathrm{S}$ : because he can.......

$\mathrm{T}$ : nooo he got the most dangerous radioactivity. the effect is very dangerous for him. and............ to be fixed. so someone is too close will get more danger. so why did he ask the coworkers to do that?? lha ini use your logic. why did he ask the co worker to mark his ....Adi coba yang sudah mesam- mesem dari tadi.

A : because he want to measure the reaction area I mean the length of the reaction itself. so if he can know the position of someone when the reaction happens maybe he can calculate how.. how..great the risk the close person will have

From the 2 different times given by the lecturer for the students to students to call the students' name to answer the questions were applied to deliver different questions and they also gave good effects on the students. The lecturer needed more than 3 seconds when she gave high-level questions and less than 3 seconds when she asked low-level questions. This lecturer's behaviour gave the students a very good effect that they have enough time to answer the questions and sudents didn't feel stressed or pushed by the lecturer that finally affect their answer. 


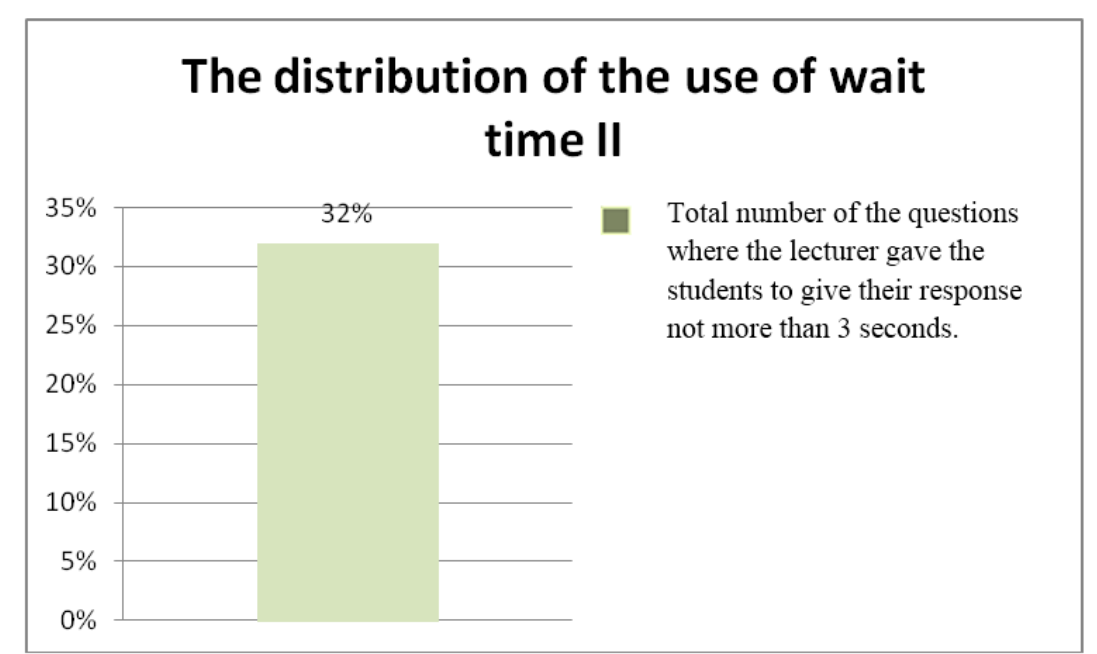

Figure 2 : The use of wait time 2 by the lecturer

Figure 2 shows wait time 2 where lecturer gave the lecture gave the students to give their response to the questios given. From the observation, it could be seen that students mostlu couldnot answer the questions well when they were given not more than 3 seconds to answer the question. The just answered the questions in a short answer. It was different when they were given more than 3 seconds to answer the question. They could answer the questions better3 because they had enough time to think. Moreover, students looked stressed ewhen the lecturer pushed the students to answer the questuions directly.

\section{The Use of Nonverbal Behaviors}

The results of the observation showed that nonverbal behaviors were also used by the teacher other than verbal behaviors when asking questions. Some nonverbal behaviors such as maintaining eye contact with students, nodding head, using facial expression and using hand gesture. There were differences on the frequency of the occurrence s of each nonverbal behavior as what could be seen in the following figure:

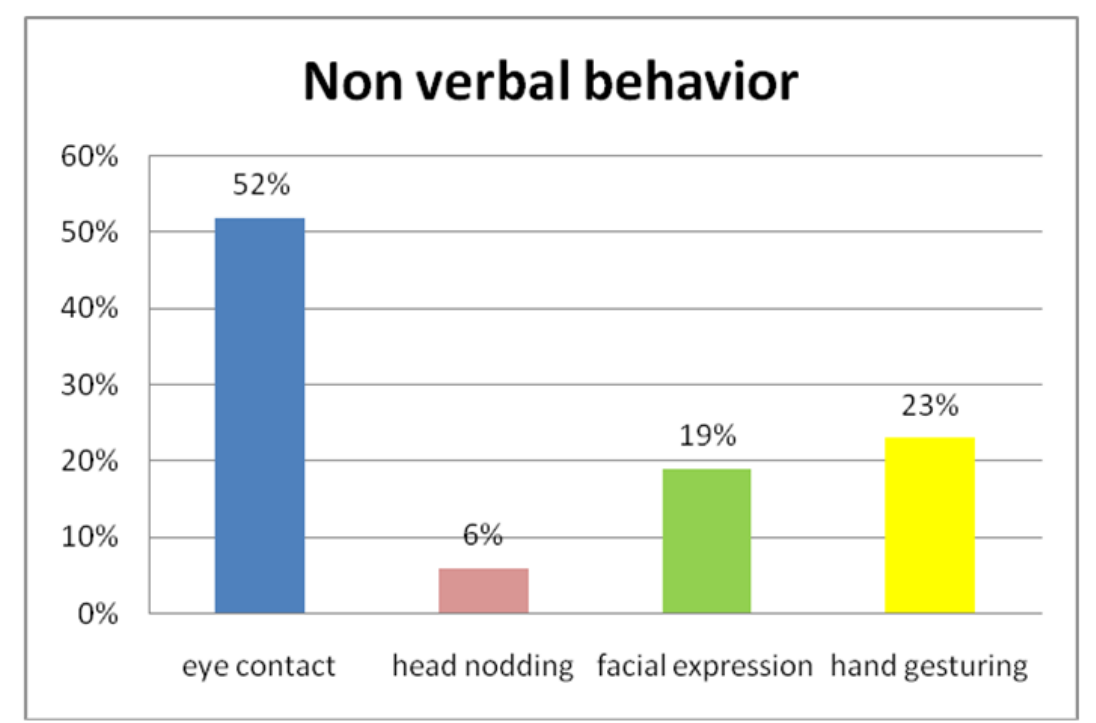

Figure 3: The Lecturer Nonverbal behaviors for Asking Questions in Reading classrooms 
Figure 1 showed different frequency of the use of nonverbal behavior. From the figure, it could be seen that the lecturer paid good attention to the students by always maintaining eye contact when she asked questions to the students. It took $52 \%$ of all questions asked. This behavior of course gave good effect for the students as what Brown (2004:263) said that eye contact can signal many messages like, interest, boredom, empathy, hostility, attraction, understanding, misunderstanding, and other messages.

Moreover, the lecturer also maintained her other nonverbal behaviors when she was asking questions. She used different nonverbal gestures such as nodding her head, using facial expression and hand gesturing to keep on the students' response. Nodding the head took $9 \%$, facial expression $16 \%$, and using hand gesture $23 \%$. Those non verbal gestures gave a good effect for the students to keep focusing on their response. Davis (1993:89) says that gestures like nodding or pointing help to keep the focus on students' responses rather than shifting attention to the teacher.

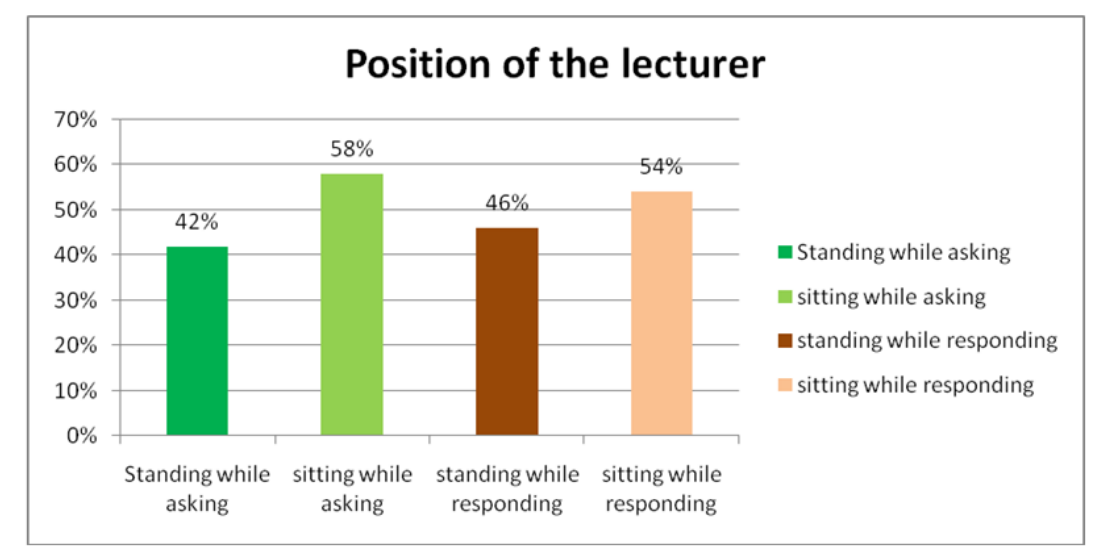

Figure 4: The position of the lecturer when she was asking questions and listening to response

In asking and responding the questions, the lecturer put herself in different position. She used to sitting more than standing. From the observation, lecturer tended to sit while giving questions or listening to response because she felt more comfortable to do so. Of course, that behavior gave different effect to the students' response.

\section{Calling on Students}

In some cases, lecturer needs to point students to answer the questions. He/she needs to call them to answer. Calling them can be done through different ways. The lecturer can directly call the students' names, let the students have their own initiative to raise their hand (volunteer), or ask all students in the classroom to answer the questions together. That what the lecturer did in the classrooms. She did calling the students to answer the questions in different ways. Figure 5 shows the percentages of the lecturer's behavior in calling the students: calling names before asking, calling names after asking, calling for volunteers and asking the whole class 


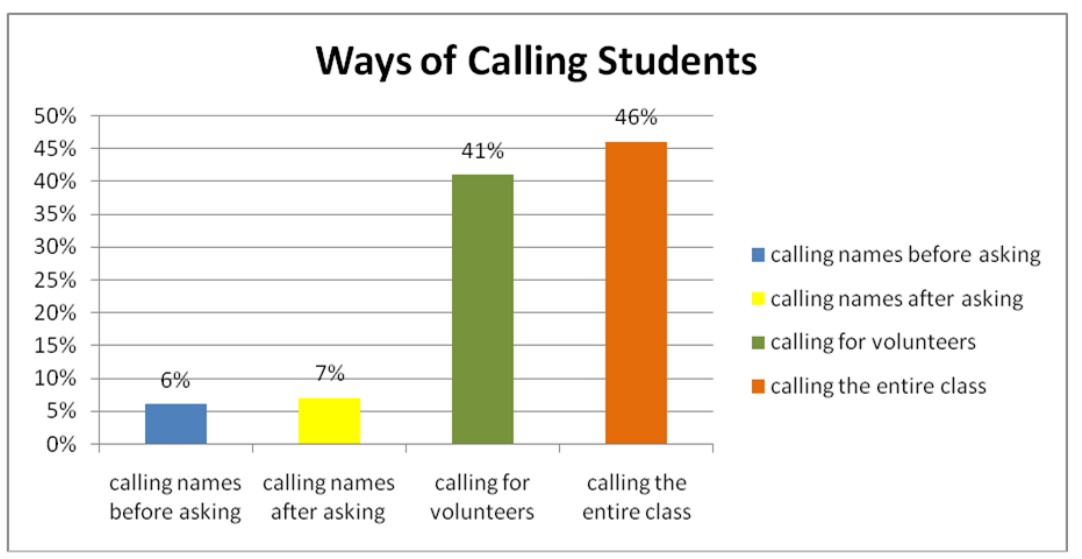

Figure 5: Ways of Calling Students to answer

Figure 5 shows different distribution of the ways of the lecturer in calling the students to answer the questions. $6 \%$ was done by calling the name of the students before asking the questions, $21 \%$ by calling names after asking questions, $41 \%$ by calling for volunteers, and $46 \%$ by calling the entire class. From the distribution, it could be seen that the lecturer rarely did calling the name of the students in asking the questions.

Calling the students' name before giving the question which took $6 \%$ give at least two advantages (Bond:2007). First, the teacher can make sure about the good and wide variety of engagement during the lesson. Second, all students clearly know whom the teacher is addressing and thus management problems should be minimized. This can be achieved by calling the students' name randomly. The students will closely pay attention s ince they don't know who will be called by the teacher to answer the questions. Moreover, calling the students' names after asking questions which took $7 \%$ also gave different advantages. It encourages the students to listen and prepare their answers in anticipation of being asked (Cohen:2005). "To keep students on their toes" teachers need to use the element of surprise and uncertainty.

[14] L : next pls. Novi would you please. Novi tu mahasiswa yang paling anteng selama saya mengajar. padahal saya sudah mengajar 35 tahun

Ss : woooooow

L : no 8 ya

$S:$ in $29 \ldots . . . D$

[15] L : can we cross out/can we omit the word if requested. I ask you Agung

$\mathrm{S}$ : cannot. for myself it cannot.

L : why?

S : because ... the senior students would, if requested, perform in outside theaters during the evening

The excerpts above are the examples where the lecturer called the name in asking the question (before and after). These ways were done to give students who were very passive in the class. The lecturer tried to give the student to chance to interact by calling the name and of course it forced the student to communicate. Calling the name before asking the question to the passive student gave a good effect where she could prepare the answer. From the observations, when the lectures asked 


\section{E. Handling Students' Responses}

The lecturer did handling the students' response by different ways from positive to negative ways. Correct and incorrect responses were handled differently as can be seen in figure 6 below.

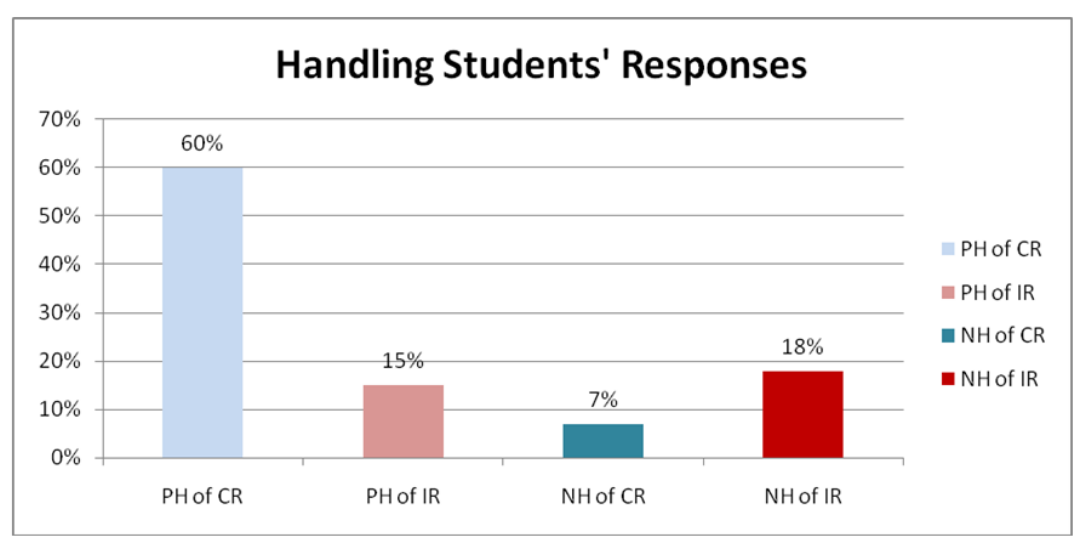

Figure 6: Lecturer's handling Students' Responses

From the figure above, it could be seen that the lecturer did a good behavior in handling the students' response. She highly appreciated and encouraged the students by positive way to their response of the questions.

\section{CONCLUSION}

Using appropriate non-verbal questioning behavior is very important as using the questions themselves. Wait time is very important to give students a chance to prepare their answer. Giving wait time less than 3 seconds are appropriate for lowlevel questions and for high level-questions, more than 3 minute wait time is needed. Moreover, gestures like eye contact, nodding head, facial expression and hand gesturing are very important to be maintained to make the students feel comfortable to answer the questions. Calling the students' name sometimes give good effect to the students where they can focus to the questions given by the lecturer and can make the passive students to participate. While calling the volunteer which can give any students to participate also brings negative effect where there will be students who dominate the class. Moreover, calling the entire class makes the lecturer get unclear answers. Handling the students response positively both by gesture or complimentary words gives students confidence to be more active in the class while negative handling can make the students feel embarrassed and stop participating.

\section{REFERENCES}

Brown, H.D. (1994). Teaching by Principles: An Interactive Approach to Language Pedagogy. Englewood Cliffs, New Jersey: Prentice Hall

Chaudron, C. (1988). Second Language Classrooms: Research on teaching and learning. Cambridge: Cambridge University Press.

Davis, B.G. (1993). Tools for Teaching. San Fransisco: Jossey-Bass Publisher

Hall, G. (2011). Exploring English Language Teaching: Language in Action, London: Routledge. 
Long, M, H., Sato, C. J. (1983). Classroom foreigner talk discourse: Forms and functions of teachers ${ }^{e e}$ questions. In H. W. Seliger \& M. H. Long (Eds.), Classroom Oriented Research in Second Language Acquisition (pp. 3-34). Rowley, MA: Newbury House.

Nunan, D. (1989). Understanding language classrooms: A guide for teacher-initiated action. Hemel Hempstead: Prentice Hall

Nunan, D. (1991). Language Teaching Methodology. Hemel Hempstead: Prentice Hall.

Nunan, D. (1992). Research methods in language learning. Cambridge: Cambridge University Press.

Orlich, et al. (2004). Teaching Strategies: A Guide to Effective Instruction. Boston:Houghton Mifflin Company.

Richards,J.C. and Lockhart,C.(1996). Reflective Teaching in Second Language Classrooms. Cambridge: Cambridge University Press.

Rymes, B. (2008). Classroom Discourse Analysis: A Tool for Critical Reflection. Cresskill, NJ: Hampton Press.

Walsh, S. (2006). Investigating Classroom Discourse. London and New York: Rutledge. 